\title{
Legal Presumptions in the Context of Contemporary Criminal Justice.
}

\section{Different Expressions of Presumptions}

\author{
TOMAS RUDZKIS* \\ Artūras Panomariovas**
}

\begin{abstract}
Since Ancient Rome, presumption has occupied a strong position in jurisprudence. It is considered a legal category, a certain device of legal technique, which provides an opportunity to move from a known fact and its relation to other facts to an implied or supposed 'fact' when there is no or limited knowledge. In practice the use of presumptions helps to shorten the span of time used to solve a particular case. In such a way it saves means for the state and all the parties involved in legal procedure, and draws less on intellectual resources of participants involved in legal proceedings.

Variety and prevalence of presumptions is based on three elements: social policy of the state, aspiration to optimize the law and aspiration to provide flexibility, consistency and clarity in legal relations. In nowadays jurisprudence, classification of presumptions into legal (in the narrow sense) and factual, deniable and undeniable ones are the most important because any legal presumption, in the broad sense, causes certain procedural consequences. Usually one of procedural parties gets relief from the burden of proof and upon the other one the burden is transferred (praesumptio iuris et de iure is an exception to this rule). Different presumptions serve different purposes, e.g. helping to go from a well-known fact to a supposedly known fact or to balance various potentials (opportunities) of the parties to the process in order to make them as equal as possible. This is due to the fact that the same term is used for various elements of legal technique that are of different origin and form.

However, not all legal categories which fall under the term of 'presumption' can be recognised as being proper presumptions. In this article, while proceeding with the study of the conception of presumption, ${ }^{1}$ the meaning of presumptions is revealed, the way they are expressed is presented and, with the help of mathematical argumentation, an attempt is made to explain why iuris et de iure forms of presumptions should not fall under the category of legal presumptions.
\end{abstract}

Keywords: Presumptions, criminal proceedings, probability, praesumptio iuris tantum, praesumptio facti, praesumptio iuris et de iure.

\section{INTRODUCTION}

Since Ancient Rome, presumption has occupied a strong position in jurisprudence. It is considered a legal category, a certain device of legal technique, which provides an opportunity to move from a known fact and its relation to other facts to an implied or supposed 'fact' when there is no or limited knowledge. In practice, the use of presumptions helps shorten the span of time used to solve a particular case - it saves means for the state and all the parties involved in legal procedure and draws less on intellectual resources of participants of the process. However, not all legal categories which fall under the term of

* Senior Research Fellow at Criminal Justice Research Department Lithuanian Law Institute tomas.rudzkis@teise.org

** Associate professor at the Institute of Criminal Law and Procedure Mykolas Romeris University arturas@mruni.eu

1 Rudzkis, Tomas; Panomariovas, Artūras, 'Legal Presumptions in the Context of Contemporary Criminal Justice. Formulation of a Paradigm' (2016) 57/4 Hungarian Journal of Legal Studies 46276. 
'presumption' can be recognised as proper presumptions. Although the effect of an occurrence of various presumptions is almost identical, different presumptions serve different purposes: ${ }^{2}$ they are used not only to go from a well-known fact to a supposedly known fact, but also to balance various potentials in order to make them as equal as possible.

This article proceeds with the study on the conception of presumption; ${ }^{3}$ reveals the different meaning of presumptions and the ways they are expressed and a mathematic based explanation is made why iuris et de iure forms of presumptions should not fall under the category of legal presumptions.

\section{SIGNIFICANCE OF PRESUMPTIONS}

There is not a single branch of law, which in one way or another avoids the use of presumptions. Presumptions, for obvious and easily understood reasons, are most often used in various procedural laws but they also exist in substantive law branches. Presumptions plays an important role in the proper regulations of social relations. Presumptions are often given legal principles form such as prudence, honesty, common sense, knowledge of legislation, etc. In criminal proceedings and criminal laws, other presumptions are used widely as well as presumptions, which are given the form of legal principles. These other presumptions include the impartiality of the pre-trial investigation officer, prosecutor, judge, secretary of trial hearing, translator and specialist or expert; legal procedural capacity of parties to the process and other persons that take part in procedural activities as well as awareness of rights and responsibilities; equality of evidence, responsibility, dropping the charges, justice and legitimacy of a court decision that has gained a power of res judicata; legitimacy and validity of pre-trial testimony given to a judge by witnesses, victims and suspects and awareness of information published by the press about the court session.

Such variety and prevalence of presumptions is determined by the following closely related and complementary reasons:

(a) Social policy of the state.

Presumption is a compact written reflection of social policy of the state in the law the materialization of social policy, conducted by a particular state in certain spheres of social activities. For example:

- The 'black lung' presumption was legalized in the US when the Federal Coal Mine Health and Safety Act of 1969 came into force, setting national health and safety standards of US coal mine for the industry and social guarantees for the miners. It enabled miners totally disabled by pneumoconiosis (or 'black lung' restrictive decease) to receive periodic payments and if death had occurred members of the family of deceased miner would be paid compensations for loss of the breadwinner. ${ }^{4}$

- Parental presumption - the protection of child interest ${ }^{5}$. The idea has kept its original form and content since ancient Roman times despite of occurrences of new methods of proof.

\footnotetext{
2 Larkin and Herasimchuk (1993) 244.

3 Rudzkis and Panomariovas (2016).

4 Federal Coal Mine Health Act of 1969 (2010) link 1.

5 For more information see Murphy (1992) 564-65.
} 
- The child birth presumption is the same as the parental presumption - in cases where it is not possible to determine whether the child was born dead or alive, the child is presumed to be born alive. $^{6}$

- Judicial impartiality - this presumption idea is based on the confidence in the courts. In democratic society, confidence in courts is essential for normal functioning of the judicial system and judicial impartiality should not cause any doubts unless data are presented that allows asserting the contrary. This presumption is quite strong. For the parties to the process to prove that the court might be predisposed is not easy, as it may appear at first sight. These evidentiary difficulties are also confirmed by the jurisprudence of European Court of Human Rights. A number of judicial bias and/or interest complaints were filed in the European Court of Human Rights. However the Court has only once concluded that the applicant had a reason to doubt judicial impartiality - in the 2003 case, Pétur Thór Sigurdsson $v$ Iceland. The Court noted that impartiality should be determined by a subjective test, i.e. in every single case, it is determined by personal belief of the judge and by objective survey whether the judge has put in all effort to remove any doubts about their bias. According to a subjective test, personal impartiality of the judge should be presumed, until proven otherwise. An objective test should help to determine where there are any real facts, regardless of the personal behaviour of the judge, that raise any doubts regarding judge's impartiality. Any judge, in respect of whom legitimate doubt arose, must withdraw from the case. It means that if there is a reason to doubt that in a particular case the judge, while making a decision, might be biased, the worry of a person concerned is important, but not decisive. The decisive factor is whether such doubt is objectively justified. ${ }^{7}$

(b) Aspiration to optimize the law and make legal proceedings cheaper.

Presumptions help to save time and efforts for the parties to the process, as well as for the court, when trying to prove and evaluate something that is obvious and may be disputed only in rare occasions. ${ }^{8}$

A trial is a costly procedure, which requires lots of time and means. The tax payers contribute to the support of legal system, ${ }^{9}$ also the parties to the process suffer financial burden, related to preparation and conduct of the case, stamp duty, etc., pay for administration of justice. Therefore there is an obligation and a strong drive to be economical. Economizing on resources may happen in various ways and one method is dialogue or encouragement of cooperation.

It is ideal when procedural parties, in order to better implement the objectives of the process and their needs, willingly cooperate with each other and also with the court ${ }^{10}$ in order to save the time and resources of the parties to the process. Presumption is one means (element) of legal techniques with which it is possible to encourage the dialogue between the parties in a dispute, along with cooperation between the court and the parties to the process in order to allow everyone to achieve their goal.

Any dispute sooner or later reduces down to the situation that one party claims something that the other denies. Such undetermined situation cannot last for indefinite period of time. Presumption is one of the ways to solve such uncertainty and continue the

\footnotetext{
${ }^{6}$ Section 2.2, Part 3 of Civil Code of the Republic of Lithuania (2012) link 2.

7 Pétur Thór Sigurđsson v Iceland (2003).

8 James (1961) 66.

9 Bernardo et al (2000) 2.

10 Walton (2008) 211.
} 
previous dialogue between the parties to the process. ${ }^{11}$ One effect caused by presumption is the distribution of the burden of proof, which allows the artificially transfer of the burden of proof from one procedural party to another. However this does not mean that the party, released from the burden of proof is not obliged to answer procedural arguments of another party, on which the burden of proof lays upon. ${ }^{12}$ In the same process, the burden of proof may be transferred from one procedural party to another a number of times. In this way the dialogue between the parties of the process is encouraged. The court, for its part, must observe and regulate the process in such a way that the burden of proof was transferred to the party that knows and is aware of certain facts, but not to the party that does not know or denies it. This is so, because most of the times facts which are denied must not be proven (negatava non probantur). When presumption, as a certain legal measure, is given to the party of the process that denies something, it additionally encourages the procedural party which asserts to be more active. The reverse is also true, when presumption is given to the party that claims something, then the denying party of the process is obliged to act more actively.

Another question is whether it is possible to try to prove something that is being denied, because usually a negatava non probantur rule is in force. The answer to this question is positively answered. Denial, which has the positive (determined) statement encoded within, can be proven and vice versa, the denial, which has a negative (undetermined) statement encoded within, cannot be proven. For instance:

(1) the accused (the suspect) denies that during the commitment of a criminal offense they were at the place of offence and claims that they were somewhere else and that they can name the place. In such situation, the accused (the suspect) has an objective opportunity to prove that during the commitment of criminal offence, they were not at the place of the offence by presenting supportive and conclusive data.

(2) the accused (the suspect) denies that during the commitment of a criminal offence they were at the place of offence and claims that they were somewhere else. However, they cannot tell exactly where they were and can only indicate an approximate location, which cannot be clearly identified. For example, 'I was jogging alone in the forest at that time' [negative (undefined) statement]. In this situation, the accused (the suspect) has no objective opportunity to prove whether the statement is true, as they does not indicate the place of their presence during the offence and names it in an abstract (undefined) manner. The outcome is that they cannot prove the statement that they were not in the place where the criminal offence occurred. In such situation the version of the defending party, in terms of information, is considered null and void, if an exact location cannot be indicated. The prosecutor has then an opportunity to concentre on averment of the validity of his own claim, the validity of which might be proven in case he does not cross certain boundaries of time and (or) space (location).

Thus, the rule that denial cannot be proven is applied only to a particular denial that is presented in undetermined form, i.e. in the form that is not defined by the factors of time and (or) space (location).

(c) Aspiration to provide flexibility, consistency and clarity to legal relations.

Presumptions have an impact on social relations and whenever there is a lack of information (or knowledge), it is made possible to go from certain fact onto the supposedly

11 Walton (2008) 211.

12 Walton (2008) 211. 
known fact and to fill the lack of information (knowledge). The source of power of presumption is the inability to find out the truth relying only on well-known and undoubted information at all times. A presumable fact (phenomenon, occurrence, etc.) is not identical to a certain fact. When true (sure) knowledge is absent, presumptions do help because as the result of logical thinking, they contribute to overcoming uncertainty of information and find a solution in a particular situation. For instance, the presumption of death - in case if within three years, there is no information about the person's presence in the place of residence, it is being presumed that they are dead. Besides the social function, i.e. protection of interests of the person, whose presence was not known for the period of three years in their place of residence, it brings clarity to legal relations at the same time. The person is declared dead, which means their civil status has changed, they become a testator and their successors acquire the right to inherit the assets of the testator. Other forms of presumption of death serve the same purpose - provide clarity and flexibility to legal relations, as they help to find the way out of the legal impasse:

- the presumption of 'the moment of death' is laid down in Article 109 of the Civil Code of Argentina - if two or more persons died in an accident, it is being presumed that they have died at the same moment and they do not gain succession of rights. ${ }^{13}$ Presumption of the same content is laid down in Article 2.2, Section 4 and Article 5.3 Section 2 of the Civil Code of Lithuania. While in England, presumption of 'the moment of death' has a slightly different content - if two or more persons died because in accident or other circumstances, it is being presumed that they died in accordance with their age: the oldest one - first and the youngest one - thereafter.

- the presumption of 'loss of the ship' is laid down in Article 194.2 of the Civil Code of Spain. If, within the period of three years since the moment the ship has left the port of departure or since the last information about it was received, the ship has not reached the port of destination and if it is not present in the port of departure, it is presumed, that the ship is lost and the crew is dead. ${ }^{14}$

- the presumption of 'the known address' is consolidated in Articles 138 and 139, Section 1 of the Code of Criminal Proceedings of Poland ${ }^{15}$ which reads as:

(1) a party to the process (as well as the person who is not a party to a process, but whose rights have been infringed), while being abroad, must provide the national address for correspondence and it is being presumed that the letter (or note) was handed to the person, if it was sent to an indicated address, even if such address does not exist.

(2) if the party in criminal proceedings has not provided the information regarding the change of the place of residence or stay, it is being presumed that the letter (note) was handed to the person, if it was sent to the known, most recent address.

- the presumption of 'dropping the charges'. If a private accuser and his attorney do not appear in conciliatory meeting or hearing without a justifiable reason, it is being presumed that the private accuser has dropped the charges (Article 413, Section 6 and Article 416, Section 2 of the Code of Criminal Proceedings of Lithuania; ${ }^{16}$ Article 491, Section 1 and Article 496, Section 3 of the Code of Criminal Proceedings of Poland).

13 Mendonca (1998) 406.

14 Mendonca (1998) 406.

15 Code of Criminal Proceedings of the Republic of Poland (2012) link 3.

16 Code of Criminal Proceedings of the Republic of Lithuania (2012) link 4. 


\section{FORMS OF PRESUMPTIONS}

Presumption consolidation forms are often considered a criterion which is used to assort dominating presumptions. Often in legal literature, the opinion is expressed that presumptions cannot be classified and all the attempts to group them would result in confusion instead of being of practical benefit. ${ }^{17}$

It is worthy to analyse different expression forms of presumptions and their classification at the same time as the law acknowledges various forms of presumptions, which are not equivalent and, depending on their form, may result in legal and actual consequences. Moreover, there is no consensus indicating basic criteria according to how presumptions should be assigned to forms. This issue becomes especially important when presumptions are studied from the systematic point of view and not from the point of view of one branch of law.

Traditionally presumptions, depending on their consolidation forms, can be classified into legal (praesumptio iuris) and factual (praesumptiones hominis seu facti, praesumptio facti or praesumptiones hominis).

Legal presumptions are considered to be presumptions which are defined or derived by legal norms. The factual presumptions on the contrary, are not defined by legal norms and are considered something that derives from everyday life - normal living, self-evident and true. However, everything that is unusual, not from real-life, unless proven otherwise, is considered not true or contrary to the truth, e.g., parents loving their children; people takes care of their own business and everyone acts according to common sense are all based on this provision. Such presumptions are not regulated by law. In 1842, US lawyer Phillipps wrote that factual presumption is the act of thinking, when, using common sense, based on something that happens, the conclusion is arrived at about existence of another possible fact. ${ }^{18}$

Sometimes it is being stated that commonly known facts, which are accepted for criminal proceeding as obvious and do not require any proof, are also considered factual presumptions. However, such statement, the same as an attempt to assign the category of 'well-known facts' to the presumptions, in our opinion, is not true and creates confusion.

Unnecessary confusion and formation of a false opinion that well-known facts are presumptions is determined by the statement that 'well-known information' does not require any proof (notoria no egent probatione). If information does not require any averment, it should mean that they are presumptions, but something, that does not require any proof, is not necessarily a presumption or is on the way to become one.

'Well-known facts' or 'presumption' are close to one another but not identical. This difference is indicated by their origin: the term of 'presumptions' derives from Latin word 'praesumptio' and 'well-known facts' derives from Latin word 'notoria' (news, information).

In order for well-known facts to become means of proof, it is necessary that those facts should be acknowledged by both parties of the process and the court (lex non requirit verificari, quod apparet curiae). Only the party of the process, which leans on 'notoria', gets relief from the burden of proof. In the case of presumption, the burden of proof is distributed between the parties, no matter if they acknowledge a presumable fact.

17 Murphy (1992) 562.

18 McBaine (1938) 524. 
In comparative law, comparative legal method sometimes refers to praesumptio similitudinis - the presumption that similar problems result in similar answers in different legal systems. ${ }^{19}$ The various difficulties faced by one person require a lot of energy and are time consuming, especially during reasoning process when decisions should be made in uncertain circumstances. The majority of the problems can be solved by applying special decision-making rules, i.e. using a specific problem-solving algorithm, but usually this algorithm is replaced by a simple procedure that helps find adequate, through often imperfect, answers to difficult questions ${ }^{20}$, e.g. by employing heuristic thinking or analogue reasoning. The introduction of such probabilistic methods of reasoning in everyday human activities is further facilitated by the (non)deliberate introduction of presumptions. People, when deciding on the probability of a particular event, assess how much that event or fact is similar to that which is typical for one or another population - how easily it is attainable. Praesumptio similitudinis is one of those examples showing how to facilitate the reasoning in finding a solution to a specific problem, although such a solution is not always correct. In the system of continental law tradition, presumptions of facts (German tatsächliche oder einfache Vermutungen; French presomptions de l'homme ou presomptions simples; Italian presunzioni semplici) have no binding effect, for they are inferences which a judge with their free discretion may draw from certain facts to other factual matter. In this, everything is left to the wisdom of the judge who shall use them only 'if they are weighty, exact and consistent'. ${ }^{21}$

Separation of presumptions into factual and legal ones is generally accepted and also acknowledged by European Court of Human Rights. The Court referred to the separation of presumptions into factual and legal ones, their acceptability and possibility to make decisions based on presumptions in specific occasions already in 1988, in the case of Salabiaku $v$ France, while noting that an easy transition from the idea of criminal liability to the concept of guilt illustrates relativity of similar separation. The Court argued that every legal system acknowledges factual and legal presumptions and it also stated that the Convention of Human Rights does not oppose that but, in regard to the criminal law, it obliges contracting states not to cross the boundaries of common sense, considering the seriousness of the case and preserving the right of defence. ${ }^{22}$

Separation of presumptions into factual and legal ones as to whether they are laid down in legal act is too formal and not exact or appropriate. The separation of presumptions into legal and factual ones is generally accepted but does not provide an answer to the question, which presumptions are or might be considered factual and which ones are considered legal. The fact that presumption first and foremost is a legal category puts in doubt that such separation is correct. It may be assumed that all presumptions, which are used by law, in a broad sense are nothing else but legal presumptions. This presupposition is supported by the legal doctrine of some European countries. For instance, Germanic (Austria, Germany, Swiss) doctrine distinguishes 'genuine presumptions'. They are called legal presumptions (gesetzliche Vermutungen), which, in turn, are regarded as legal norms (Rechtssätze) and have two forms: factual (Tatsachenvermutungen) and legal (Rechtsvermutungen). ${ }^{23}$ However such assumption is not correct when considering all

19 Pfeiffer (2014) 203.

20 Kahneman (2011) 98.

21 Lenhoff (1954) 333.

22 Salabiaku v France (1988).

23 Fankhauser et al. (2016) 195. 
existing legal systems and therefore, this discussion is about the system of continental law tradition not common law tradition.

The main effect of application of presumption is distribution or re-distribution of burden of proof between the parties of the process. If, besides legal presumptions (that are understood in the broad sense), there would be a separate category of factual presumptions detached from legal presumptions, it would mean that presumption, despite of its form should basically produce the same legal consequences - whether it is a presumption that is acknowledged by law or presumption, that arises from real life. One party of the process, usually the one that leans upon presumption, should be exempt from the burden of proof and the other party of the process should be given this burden. However, this is not so, because legal consequences are caused and may be caused only by presumptions, which are acknowledged by statutory law or (and) case law. Therefore the assumptions, which are not consolidated in law in one form or the other, are rather moral categories, beliefs that arise from living experience and may be called factual 'presumptions' only in relative sense. ${ }^{24}$

Such a statement is only correct under one condition that separate categories are not considered identical, i.e. category of well-known facts ('notoria') and category of assumptions, arising from living experience. It should be noted that presumptions, which are not consolidated by statutory law in one form or other, but arise from living experience, can cause certain legal consequences in the common law system. ${ }^{25}$ For instance, when a jury faces presumptions, that are not consolidated by legal norms, but arise from living experience, it can, but is not obliged to, follow them. ${ }^{26}$

It does not mean that these conditional factual presumptions or assumptions, that arise from living experience and which are not consolidated into legal environment of continental law system are not significant to the law of those states and should be ignored.

When the legislator creates legal norms, they use conditional factual presumptions in order to justify necessity of a newly established norm, in one way or another. Conditional factual presumption may become an inner motivation, which determines appearance of a new legal norm. Thus, a conditional factual presumption may be considered a sort of social and legal reference, an important criterion, under guidance of which new norms are added to the legal system or validity and necessity of newly proposed norms is being evaluated upon.

Over time, certain conditional factual presumptions may gain the form of a legal norm and in this way the law arises from the fact (ex facto ius oritur).

A conditional factual presumption may also be used as a kind of logical argument in the process of application and interpretation of the law. For instance, in criminal proceedings 'presumption of innocence' is considered principle maxima. But in separate cases 'presumption of silence', i.e. provision 'consentire videtur qui tacet' (silence means consent), is being used as an argument during the accusation of the presumably guilty one. Thus a deviation is made from the rule, which says that the doubt that arises in regard of the guilt of the accused party should be interpreted in favour of the accused (dubia iudicis de malitia alterius semper sunt in meliorem partem interpretanda). For example, the European Court of Human Rights in the case of Murray $v$ the United Kingdom ${ }^{27}$ decided that, if prima facie arguments are presented and the burden of proof is up to the accusing party, negative conclusions should be drawn in case the accused refuses to testify. The requirement for the

${ }^{24}$ Infra they are called 'conditional factual presumptions' or 'social factual presumptions'.

25 Murphy (1992) 562-64.

${ }^{26}$ Kenny (1915) 326.

27 John Murray v the United Kingdom (1996). 
accused to testify was seen as not incompatible with European Convention of Human Rights. However, if the conviction was totally based on refusal of the accused to testify, it should have been seen as incompatible. Whether the negative conclusions, based on refusal of the accused to testify, infringes their right of presumption of innocence, is determined in accordance with the meaning given to these conclusions by national courts. They evaluate the evidence and, for example, the level of constraint that was used. The evidence of the prosecution should be strong enough in order to require a response from the accused. National court cannot arrive at the conclusion that the accused is guilty only because they decided not to testify. Only when the evidence against the accused 'requires' explanations, which they should be capable of providing, but refuses, it is possible to draw a conclusion that the accused is guilty. On the contrary, if the prosecution arguments are weak to the degree that they do not require any response, refusal to testify cannot justify the admittance of guilt. The European Court of Human Rights points out that justified conclusions made from the behaviour of the accused may affect the transfer of burden of proof to the defendant, but should not infringe this aspect of principle of presumption of innocence.

Conditional factual presumptions are significant to the law and can be considered in a court's decision. But as long as they are not consolidated by legal act, in one way or another, these presumptions will not be proper presumptions, application of which is mandatory and which lead to direct legal consequences.

Roman law scholars ${ }^{28}$ indicate the following features of presumption, which may cause or causes certain legal consequences:

(a) the power of legal norm ' $<\ldots>$ quod praesemptum esse debet, nisi contrarium ab herede approbetur' (presumption is something that might be true unless proven otherwise);

(b) that obliges while reasoning to acknowledge the facts, existence of which rises doubts 'quod si non evidenter apparuit' (if it is not obvious), as true, unless proven otherwise;

(c) the facts should be related to external events, phenomena, objects or inner order. An external event could be theft, debts, genesis ('ingenuitatis'), servitudes ('servitutis'), society ('societatis') etc. and will ('voluntas'), for example, falls under inner order.

In fact, all these features are typical for modern presumptions:

(a) the power of legal norm, which means that presumptions should be consolidated by legal norms (direct consolidation) or might be derived from legal norms by explanations (indirect or derivative consolidation).

(b) the presence or absence of relation to other circumstances (facts, phenomena, events, legal relations, etc.) of legal significance and causing certain legal consequences.

(c) the presence of obligations to acknowledge as established circumstances, existence of which lacks sufficient data, without additional evidence, if not proven otherwise.

At the beginning in Ancient Roman law praesumptio facti or praesumptio hominis seu facti was a result of court actions, which used to acquire a substantive form of presumption only when they were consolidated in a particular decision of the court. Praesumptio facti was a hypothetical conclusion, which the court arrived at after analysing true, known facts. However such a conclusion was not mandatory for solving other cases. ${ }^{29}$ To make any summarized provisions or create common principles from this type of presumption that would be generally mandatory was not possible. The judge, who had to rule when there was lack of information, ex officio or using his personal experience, would acknowledge, that

28 Donatuti (1976) 421, 424.

29 Macagno (2012) link 5. 
there is a particular fact, the presence of which is not proven by any information. ${ }^{30}$ When the judge had information about one given fact, he was forced to make an assumption about the existence of another, unknown fact, which might have been related with the fact that is already known. For example, Antonino Pio was dealing with a dispute that arose from a loan agreement regarding the payment of interest, when the creditor did not require the debtor to make interest payments for a long period of time then suddenly required interest payments. The judge decided that in this case, considering the circumstances, that the creditor did not require interest payments from debtor for unreasonably long period of time, they were not dealing with the type of loan agreement that obliged the debtor to pay an interest on the loan and therefore he did not have to pay the interest. ${ }^{31}$

Ancient Roman lawyers have discussed the guessed and assumed facts in their opinions and decisions, while using formulation verisimile est ('it is likely that'), videtur est ('it seems that there is'). All their considerations were accompanied by (or their starting point was) 'aequitas' ('justice'). It was their goal and they sincerely believed in the existence of the mentioned facts. ${ }^{32}$ Such belief was presupposed by the law itself ('ius'), since during the post classical period of Roman law, opinions of individual lawyers used to gain a power of norm. Lawyer's opinion about the existence of some hypothesised (or supposed) fact would not oblige the court to acknowledge the existence of such supposed fact ${ }^{33}$ However, in accordance with the opinion of the lawyers, they were given the right to acknowledge such guessed (or supposed) fact as true (or proven). Multiple use of lawyer's opinion regarding the existence of a supposed fact in court decisions would make this fact (praesumptio facti) a presumption of other form - praesumptio iuris. At the same time, this would trigger the court's duty to make a decision accordingly. Thus, praesumptio facti would become a mandatory presumption and would gain the form of praesumptio iuris or praesumptio iuris tantum.

Praesumptio iuris tantum enabled legal means to solve the question concerning the fact (quaestio facti), but not the law (respondit non de iure quaeritur). In this way court actions were made easier. ${ }^{34}$

Praesumptio iuris tantum were used to express a mandatory legal relation between the main (well-known) facts and other (assumed) facts, ${ }^{35}$ such as:

- in accordance with praesumptio iuris tantum: if a son would die together with one of his parents and if he was sexually mature at the moment of death, it used to be considered that he outlived his parent, but if he was not sexually mature, it was considered that he passed away before his parent;

- at the birth of twin brother and sister, the boy was born earlier than the girl. ${ }^{36}$

Presumptions of iuris tantum form are transferred into the present law. The sources of their powers are legal acts. ${ }^{37}$ They can be denied and are result of inductive reasoning, embedded in legal norm. Legal categories that are not constructed by the way of selective (incomplete) inductive reasoning method should fall under iuris et de iure category, not under the category of 'iuris tantum'.

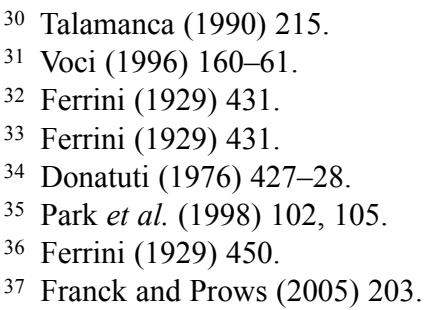


Sometimes iuris tantum presumptions are called the prima facie proof of a presumable fact. A provision set under the California Evidence Code, US can serve as an example. Solemnly conducted marriage is declared valid, however if one of the parties does not acknowledge it and the other party wants to prove that such marriage was really conducted but does not have enough data, it is sufficient just to prove that the ceremony took place. ${ }^{38}$

The standard structure of praesumptio iuris tantum norm consists of three elements. This norm is constructed in accordance with the following provision - let presumption be valid until it is proven otherwise (stabit praesumptio donec probetus in contrarium): 'if it is $\mathrm{A}$, it is likely that it is B, until proven otherwise (not B)'.

The first element of this construction (hypothesis) is a condition of the functioning of presumption. The second element (disposition) is an immediate assumption, the content of which has a likely conclusion that has to be made by the person applying the law in case actual circumstances correspond with the conditions that were mentioned in hypothesis. The third element is a contrary presumption, which provides an opportunity to deny the conclusion that was consolidated in disposition. ${ }^{39}$ Presumption of discrepancy of publicly disseminated data with reality which is provisioned in Section 2.24, part 1 of the Civil Code of Lithuania, could serve as an example of presumption having this construction.

It should be noted that in the countries which apply the system of common law, presumption may acquire iuris tantum form even when it is consolidated in court decisions. Hence, praesumptio facti, which is based on inductive reasoning of the judge, becomes an element of case law and acquires a new form of praesumptio iuris (praesumptio iuris tantum).

In 1842, Phillipps, while speaking about legal presumptions, noted that there might be two forms: the ones on which the conclusion is final, because they cannot be denied (or proven otherwise) and the ones which might be denied, i.e. they become undeniable only when they are not proven otherwise. ${ }^{40}$

It is obvious that while talking about presumptions on which the conclusion is final because they cannot be denied, Phillipps had in mind the so called indisputable, or absolute legal presumptions iuris et de iure (praesumptio iuris et de iure), when legislation acknowledges some questionable fact as proper and forbids (does not provide any rights) to prove otherwise. Iuris et de iure reminds of legal fictions (fictio iuris) by its structure. The earlier mentioned provision of 'the known address' consolidated in Article 138 and Article 139, Section 1 of Criminal Code of Poland as well as provision of "dropping the charges" consolidated in Article 491, Section 1 and Article 496, Section 3 of the Code of Criminal Proceedings of Poland and Article 413, Section 6 and Article 416, Section 2 of the Code of Criminal Proceedings of Lithuania might serve as an example of praesumptio iuris et de iure.

A probability function can be defined that meets requirements of 'sufficient plausibility' of presumption ${ }^{41}$ for analysis of presumption forms. Considering the adversarial principle of the process, in general probability of decision that will be made by the court and will favour one party, might be defined as follows: ${ }^{42}$

38 Macagno (2012) link 5.

39 Macagno (2012) link 5.

40 McBaine (1938) 524.

${ }^{41}$ For more information on stochastic features of presumptions refer to the $1^{\text {st }}$ Proposition at Rudzkis and Panomariovas (2016) 466.

42 The model is based on Bernardo et al (2000) 9, 11 . 
$q_{T}=\frac{E_{V}}{a E_{K}+E_{V}}$

here $E_{V}$ - evidence presented by one party to the process;

$E_{K}$ - evidence presented by the other party;

$a-e x$ ante (in most cases ex lege) determined appraisal of evidence (in broad sense - inadequate) that favours one party of the process.

If conditio sine qua non is not provisioned (i.e. $a=1$ ), the court is free to appraise the evidence presented by the parties. For instance, if one party does not submit the required evidence, the court will favour the other party. The more (direct) evidence the party submits, the more favourable ruling it might be awarded, i.e. better efforts of party to the process ceteris paribus increase the probability of favourable decision. However, if the court is obliged to appraise the submitted evidence in specific, pre-determined way (i.e. $a<1$ or $a>1$ ), one of the parties acquires inadequately favourable procedural status and makes the onus probandi of the other party more difficult.

Basically, situation $a \neq 1$ means that in order to appraise submitted evidence, presumption should be invoked $(a=0$ and $a=\infty$ defines the situations of absolute, undeniable presumptions, $a$ : $0<a<\infty, a \neq 1$ describes all other variations of the use of presumptions). It should be noted that according to the $\left.1^{\text {st }} \operatorname{Proposition}^{43} q_{T} \in\right] \frac{1}{2}$; 1 [, i.e. the set of presumption utilisation cases consists of the cases when $0<a<\infty(a \neq 1)$ only. Therefore the absolute, undeniable "presumptions" (situations when $a=0$ or $a=\infty$ ), cannot be acknowledged as presumptions. Thus, iuris et de iure is not, despite be widely considered as, one of the forms of legal presumptions. ${ }^{44}$

The undeniability of iuris et de iure is considered the element of legal technique, characteristic of substantive law branches. ${ }^{45}$ However, the undeniability feature does not allow to widely applying constructions of iuris et de iure form in procedural law and especially in criminal proceedings as the legal categories of such form are not compatible with idea of the search for the truth.

Iuris et de iure is characterized by the construction: 'If A, then B is supposed'. It should be noted, that Ancient Roman law did not acknowledge any form of praesumptio iuris et de iure, which is featured in nowadays law. Roman law would acknowledge the possibility of relief from the burden of proof but not of the ban of proving. ${ }^{46}$

In Ancient Roman law, praesumptio facti can be distinguished from praesumptio iuris (praesumptio iuris tantum). The question remains in law of how praesumptio facti should be distinguished from praesumptio iuris as, unlike the Roman law, praesumptio facti and praesumptio iuris are provisioned by law in one form or another?

It can be assumed that praesumptio iuris differs from praesumptio facti by the source from which inspires its power. Praesumptio iuris gains its power from the law and from logic thereafter. Praesumptio facti gains its power from its origin ${ }^{47}$ and from the law (legislation) only afterwards.

43 Rudzkis and Panomariovas (2016) 466.

${ }^{44}$ For more information on the conception of presumptions see Rudzkis and Panomariovas (2016).

45 Park et al (1998) 106.

46 Voci (1996) 161.

47 McBaine (1938) 525. 
Indeed, factual presumptions (praesumptio facti), the same as legal presumptions (praesumptio iuris), are provisioned by legal norms in one form or another. Strictly speaking they are often derived from legal norms by way of explanation of their content. The main differences between factual and legal presumptions relate to their content, but not to the form of provisioning. The content of factual presumptions consists of actual patterns of something that is most common. Praesumptio facti is derived on the basis of induction, i.e. praesumptio facti ex eo quod plerumque (presumptions arise from what generally happens).

Presumption of responsibility might serve as an example. It means that a person who committed a crime is considered responsible (non compos mentis) if not proven otherwise. Responsibility of each particular offender is not being determined in criminal process, although it is considered the subjective attribute of corpus delicti. The necessity to determine the responsibility of a particular person appears in case when certain data are discovered, which allow the assumption that the person was not totally aware of and (or) capable to control their actions during the crime. However, if such data do not appear, the pre-trial investigation officer and prosecutor get relief from the duty to prove responsibility of the offender. Presumption of responsibility is nothing but factual presumption, as the majority of offenders is responsible. In those corpora delicti, which require the negative outcome of the crime to be proven, praesumptio facti implies that the person, who committed such crime, understood the manner of their own action or non-action and that they have foreseen the consequences that are dangerous to the society, i.e. the intellectual element of intent is presumed. Other presumptions that are also used in criminal proceeding are of the same origin. For instance presumptions of 'procedural capacity', 'awareness of legal rights and obligations', 'equality of evidence', 'common sense', etc. Meantime, praesumptio iuris is invoked in the legal system purely because of legal or social reasons.

Praesumptio iuris tantum and praesumptio facti, unlike praesumptio iuris et de iure, are generally deniable presumptions and, consequently, out of those only presumptions based on the reasoning of selective induction should be recognised as proper presumptions. ${ }^{48}$

\section{CONCLUSIONS}

Variety and prevalence of presumptions is based on three elements: social policy of the state, aspiration to optimize the law and to provide flexibility, consistency and clarity in legal relations. In nowadays jurisprudence, classification of presumptions into legal (in the narrow sense) and factual, deniable and undeniable ones are the most important because any legal presumption, in the broad sense, causes certain procedural consequences. Usually one of procedural parties gets relief from the burden of proof and upon the other one the burden is transferred (praesumptio iuris et de iure is an exception to this rule). Different presumptions serve different purposes, e.g. helping to go from a well-known fact to a supposedly known fact or to balance various potentials (opportunities) of the parties to the process in order to make them as equal as possible. This is due to the fact that the same term is used for various elements of legal technique that are of different origin and form. The forms of praesumptio iuris tantum and praesumptio facti are considered valid presumptions as are, in a broad sense, all the forms of deniable presumptions constructed applying the method of selective inductive reasoning. Iuris et de iure, i.e. all undeniable presumptions, despite that they are considered as one of the forms of legal presumptions, cannot be classified as presumptions.

48 See Rudzkis and Panomariovas (2016). 


\section{LITERATURE}

Bernardo, Antonio Eugenio, Talley, Eric, Welch, Ivo, 'A Theory of Legal Presumptions' (2000) 16/1 The Journal of Law, Economics and Organization 1-49.

Donatuti, Guido, Studi di diritto Romano (Giuffrè 1976).

Fankhauser, Roland, Widmer Lüchinger, Corinne, Klingler, Rafael, Seiler, Benedikt, Das Zivilrecht und seine Durchsetzung (Schulthess Verlag 2016).

Ferrini, Contardo, Studi vari di diritto Romano e moderno (sulle obbligazioni, sul negozio giuridico, sulle presunzioni) (vol. 3 Hoepli 1929).

Franck, Thomas M.; Prows, Peter, 'The Role of Presumptions in International Tribunals' (2005) 4/2 The Law \& Practice of International Courts and Tribunals 197-245.

James, Fleming Jr., 'Burdens of Proof' (1961) 47/51 Virginia Law Review Journal 51-70.

John Murray $v$ the United Kingdom ECHR 1996-I 18731/91.

Kahneman, Daniel, Thinking, fast and slow (Farrar, Straus and Giroux 2011).

Kenny, Courtney Stanhope, Outlines of Criminal Law (Macmillan 1915).

Larkin, Murl A., Herasimchuk, Cathleen C., 'Presumptions' in Texas Rules of Evidence Handbook (2nd edn, Houston Law Review 1993) 241-80.

Lenhoff, Arthur, 'The Law of Evidence: A Comparative Study Based Essentially on Austrian and New York Law' (1954) 3/3 The American Journal of Comparative Law 313-44.

McBaine, James Patterson, 'Presumptions: Are They Evidence' (1938) 26/5 California Law Review Journal 519-63.

Mendonca, Daniel, 'Presumptions' (1998) 11/4 Ratio Juris 399-412.

Murphy, Peter, A Practical Approach to Evidence (Blackstone Press Limited 1992).

Park, Roger C.; Leonard, David P.; Goldberg, Steven H., Evidence Law: A student's guide to the law of evidence as applied to American trials (West Group 1998).

Pétur Thór Sigurđsson v Iceland ECHR 2003-IV 39731/98.

Pfeiffer, Thomas, 'The contribution of arbitration to the harmonization of procedural laws in Europe' (2014) 19/2 Uniform Law Review Journal 199-217.

Rudzkis, Tomas; Panomariovas, Artūras, 'Legal Presumptions in the Context of Contemporary Criminal Justice. Formulation of a Paradigm' (2016) 57/4 Hungarian Journal of Legal Studies 462-76.

Salabiaku v France (1988) Series A no 141.

Talamanca, Mario, Istituzioni di diritto Romano (Giuffrè 1990).

Voci, Pasquale, Istituzioni di diritto Romano (Giuffrè 1996).

Walton, Douglas, 'A Dialogical Theory of Presumption' (2008) 16/2 Artificial Intelligence and Law 209-43.

\section{LINKS}

1. Federal Coal Mine Health Act of 1969 (2010) <http://www.ssa.gov/policy/docs/ssb/v33n3/ v33n3p20.pdf> accessed July 1, 2012.

2. Civil Code of the Republic of Lithuania $(2012)<$ https://www.e-tar.lt/portal/en/legalActSearch> accessed July 11, 2012.

3. Code of Criminal Proceedings of the Republic of Poland (2012) <http://www.lex.pl/akt-prawny/-/ akt/dz-u-97-89-555-u> accessed July 9, 2012.

4. Code of Criminal Proceedings of the Republic of Lithuania (2012) <https://www.e-tar.lt/portal/lt/ legalAct/TAR.EC588C321777> accessed July 15, 2012.

5. Macagno, F., Dialectical and heuristic arguments: presumptions and burden of proof (2012) $<\mathrm{http}$ //fabriziomacagno.altervista.org/Publications2/article_last.pdf $>$ accessed July 10, 2012. 